Research.

\title{
RELATIONSHIP BETWEEN TRANSFORMATIONAL LEADERSHIP AND MOTIVATION WITH WITH EMPLOYEE JOB PERFORMANCE AT KPU BOGOR CITY AND BOGOR REGENCY
}

\author{
Ratno \\ Department of Management, Economic College of Binaniaga, Bogor, Indonesia \\ ratno.jadi@gmail.com (Ratno)
}

\begin{abstract}
Received: October 20, 2018; Accepted: November 19, 2018; Published: December 31, 2018
To cite this article: Ratno, Relationship between Transformational Leadership and Motivation with Employee Job Performance at KPU Bogor City and Bogor Regency, The Management Journal of BINANIAGA, Vol. 03, No. 02, December 2018, pp. 39 - 54.
\end{abstract}

Abstract. The purpose of this study is to determine whether there is a relationship between transformational leadership and work motivation with employee job performance partially and simultaneously. The population of this study is all employees at KPU Bogor City, Bogor Regency and Cianjur regency which is 80 employees. The sampling technique using the census is all the population used for research data. So the number of samples taken in this study as many as 80 respondents who are employees at KPU Bogor, Bogor and Cianjur.The research instrument is the questionnaire. The collected data is then processed using correlation analysis techniques with the help of SPSS (Statistical Package for Social Science) software. The results showed that: Firstly, transformational leadership has a positive relationship with employee's job performance with a value of 0.652 , this relationship fall into the category of strong relationships. While the influence of transformational leadership on employee job performance of is $42.5 \%$. Secondly, work motivation has a positive relationship with employee job performance with a value of 0.892, this relationship is categorized very strong relationships. While the influence of work motivation on employee job performance is $79,5 \%$. Thirdly, transformational leadership (X1) and work motivation (X2) simultaneously have a positive relationship with employee job performance $(Y)$ of $0,0.894$, this relationship shows a very strong relationship between transformational leadership variable and work motivation simultaneously with employee job performance variable. Influence of transformational leadership (X1) and work motivation (X2) simultaneously has affected employee job performance $(Y)$ of $80,0 \%$.

Keywords: Transformational Leadership, Work Motivation and Employee Performance

\section{INTRODUCTION}

\section{Problem Background}

Organizing Periodical General Election is totally required as the democracy medium to make people sovereignty as the main core of citizen life. The process of people democracy is started by the general election determining the legal principles, legitimate principles and credibility principles of the government supported by the people. Government which is from, by and for the people will deliver a democratic good governance. In order to make the general election meeting the expectation, an organization that manages and organizes directly the general election is required. 
Committee General Election (KPU) is an institution organizing national general election which is permanent, independent as mandated on the Constitution of the Republic of Indonesia year 1945 Chapter $22 \mathrm{E}$. This institution has the tasks, the rights and the responsibilities to organize a general election for the members of the House Representative, Districts Representative, and Regional Representative. The President and Vice President of the Republic of Indonesia as well as Chief of the regional government and Vice of the Chief of the regional government.

The Job Performance of KPU employees in Bogor city and Bogor Regencies are not excluded from the applicable process, result and capability refer to the quality and quantity output achieved by the employees of KPU of the city and Regency of Bogor executing their job in compliance with their responsibility accordingly. Job performance is defined as the result of the achievement or the extent of the achievement of an organization, and the performance is the job result achieved by a person or a group of the people within an organization which is in accordance with their duty and responsibility to pursue the organization goals legally, not against the law and in line with moral and ethics principles. Developing the job performance of City Authorities and regency authorities of Bogor will be time consuming and long-term processing. Besides of developing the supervision and training, the evaluation of the extent the achievement of their job performance has been done by the authorities of KPU in Bogor city and Bogor Regency.

The problems of the evaluation of job performance of the employees at KPU Bogor City and Bogor are the delay of the report about tne employees job performance, lack of discipline at work, slow executing the job as facility is not provided sufficiently. The ineffective and the inefficient job performance is happened due to only few of the authorities who have a legitimated education and training.

However, the evaluation upon job performance of the authorities of KPU in Bogor City and Bogor Regency is quite rare to be performed. Because of those issues, this research is important to be done not only finding out the job performance of the authorities of KPU in the city and regencies of Bogor, but also describing cause aspects of their improper job performance as they are the assets and main resources to perform the administration activities in KPU of the city and regencies of Bogor to reach the achievement. All the KPU resources of the city and regencies of Bogor will not work properly if they are not managed by the KPU authorities of the city and regencies of Bogor as the core executor of the administration.

The writer has done field observation, and has found out that the authorities of the Committee of General Election (KPU) doing their job have still encountered the following obstacles:

1. The existing authorities are not optimum to do their job, because of less authorities who work on the available deparment, so that, the service of competency improvement has not yet met the competency improvement of the commissioners, secretary and head of sub department, since the extent of authorities discipline is still low. Human Resources are still not enough, but the scope of job is very huge.

2. There are still some KPU authorities who do not know their main tasks and functions.

Besides that, the problem of absenteeism of the employees has still happened due to the minimum reward given by the institution for their achievement, nevertheless they do not love their job which is in compliance with their qualification, and their renumeration has not yet paid, and the organization does not care about the organization climate refers to organization structure and employees turnover, eventually, the employees are not responsible for their duties since there is not any reward received upon their achievement. Therefore, the expectation of having a good governance is still far away for the achievement. This kind of phenomena is required a research to be executed.

At each Job Performance Evaluation, the employees are required to finish their job in accordance with the job schedule or on the other word, they have had high job performance.. Withouth having best job performance of the employees of KPU of the city

Ratno. Relationship between Transformational Leadership and Motivation with Employee Job Performance at KPU Bogor City and Bogor Regency 
and regencies of Bogor, it is very hard to reach the goals. Job Performance Evaluation should have to be applied for the employees of KPU Bogor city and its regencieswhich is an effective system to improve their quality.

The success of an organization is depending on the employees' job performance achieved refers to their responsibility and tasks. Employees are important resources for the organization due to their talent, effort and creativity required by the organization to pursue the goals.

Transformational Leadership style is believed by lot of people as an effective leadership to motivate their subordinates to behave. According to Bernard Bass (NN, 2009) motivating employees, the management who implements transformational leadership is having the ollowing three efforts;

1. Encouraging the employees to be aware of the importance of results.

2. Encouraging the employees to put the priority of the team purposes.

3. Improving the employees' requirement more refers to self-esteem and self actualization.

The management of KPU Bogor city and its regional has been running quite good, but there are still some weakness;

1. Making the decision, the management has not yet involved all the subordinates, so that the decision made is absolute. Communication skill of the management has not yet been performed well which is how to motivate their subordinates to do their job well.

2. Lack of appreciation for the subordinates who have done their job good.

3. Lack of the transformational spirit of the leaders to change the attitude, communication and strategy to make the subordinates fully aware of doing their job well instead of being forced.

4. Lack of the subordinates' respect to their superior as the leaders since they have not reflected yet their leadership spirit and professionalism in their job.

5. There are still the tendency of like and dislike treatment of the management evaluating the job performance of the subordinates.

\section{Problems Formulation}

1. Is there any correlation between the transformational leadership and the employees' job performance happened?

2. Is there any correlation between job motivation and employees' job performance happened?

3. Is there any correlation between the transformational leadership and job motivation simultaneously with the employees' job performance?

\section{THEORETICAL REVIEW}

\section{Job performance of the employees}

According to llgen and Schneider (2006:p.94) Performance is what a person or a system has done. And it is in line with Mohrnman et al (2009: p.94) definition which is a performance consists of performer engaging in a behaviour in a situation to achieve results. It explains that performance is the efforts to pursue the achievement.

According to Mangkunegara (2009: p.67) job performance is the job result achieved quantitatively and qualitatively by an employee who has done his job according to the responsibility given. However, Widodo (2010:p.78) defined that Job Performance is the efforts doing the activity and finishing it according to the responsibility and the result expected.

Ratno. Relationship between Transformational Leadership and Motivation with Employee Job Performance at KPU Bogor City and Bogor Regency 
Refering to Sedarmayanti (2009:148). Performance is the result of the job performance done by an employee, job process of the management or an organization overall, and the result of the job should have have indicated the evidence of the job obviously and can be measured (compared to the aplicable standard) A more comprehensive definition described by Brumbrach in the study of Sujadi (2012:p.4) as follows Performance means behaviours and result. Behaviours emanate from the performer and transform performance from abstraction to action. Not just the instruments for results, behaviours are also outcomes in their own right - the product of mental and physical effort applied to tasks - and can be judged apart from result.

Refering to Pierce and Gardner (2010: p.260) Performance is the behaviours of organizational members that help meet organizational objectives. It means that the job performance of the members of organization which is supporting the organization reaching the goals. Job performance is the behaviour gained a certain outcome as the result of the employee's job performance.

The similar description is given by Rivai (2010: p.15), job performance is the willingness of someone or a group to perform an acitivity and finish it according to its responsibility and the result required.

Hasibuan (2010: p.105) described job performance is the result achieved by some one who has done his job based on his skills, experience and concern. The word of job performance refers to tasks is same with job performance.

As a matter of fact, job performance has emphasized the outcome of job function. However, what has happened during the process of job or function is the process of input to become the output. Key indicator to measure the individual job performance has come from the function of the job which is based on the written and clear standard. Moenir (2009:p.74) has described that job performance is the result of a person doing his job at a certain time and a specific measurement.

The Performance has been becoming the world's issue recently. It has happened in consequence of people requirement about services excellent or high quality. The quality cannot be separated from the standard. That is why the job performance has to be measured based on the standard. Job performance is the result of the job achieved by a person or a group in the organization which is in compliance with each person's responsibility to pursue the company's goals legally, it is not against the law, ethics and moral.

Job performance is refered to the extent of the success to perform the job and the ability to reach the stated goals. Moenir (2009: p.76), job performance is considered good and the result is success if the required goals have been achieved properly. Besides that, job performance can be described as the result of someone's achievement using his capability and action at a certain circumstance. Nevertheless, the related job performance is the result of someone' efforts and competency.

Based on the theories above, the writer has concluded that job performance is a job result achieved by someone or a group of people in an organization either quantitatively or qualitatively based on their knowledge, experience and seriousness as well as the time consumed to reach the objectives, vision and mission of the organization which is legal, not against the law and in compliance with ethics. Indicators of job performance consist of: (1) job quality, (2) job quantity, (3) on time, (4) responsibility, (5) team work among the peers and (6) contribution to the organization.

\section{Transformational Leadership}

Refering to McShane and Von Glinov (2005: p.5) described that leadership is about influencing, motivating, and enabling others to contribute toward the effectiveness and success of the organizations of which they are members.

Ratno. Relationship between Transformational Leadership and Motivation with Employee Job Performance at KPU Bogor City and Bogor Regency 
Yukl, Gary (2010: p.26) described : Leadership is the process of influencing others to understand and agree about what needs to be done and how to do it, and the process of facilitating individual and collective efforts to accomplish shared objectives.

Bertocci, David I. (2009:p.5) defined the leadership as ....an attempt to use non coercive influence to motivate individuals to accomplish some goal.

According to Jason A. Colquitt, Jeffery A. LePine \& Michael J. Wesson (2009:0.474) described leadership as the use of power and influence to direct the activities of followers toward goal achievement.

Referring to Burns mentioned on Monang Sitorus research (2010:h.6) described that leadership is defined as the purposeful behaviour of influencing others to contribute to a commonly agreed goal for the benefit of individual as well as the organization or common good.

Referring to Siagian mentioned on Sutrisno research (2010: p.214) leadership is ability of someone to influence others which is his subordinates to follow his instruction though his instruction is not convenient for the subordinates intention personally.

According to Kreitner and Kinicki (2005 : p.229) leadership is a process of social influencing where the leader has asked the participation of his subordinates voluntarily to reach the organization goals.

But, according to Handoko (2003:p.293), leadership is the ability of someone to influence other people to work together to pursue the target and goals.

Burns, James MacGregor (2000: p.244) origin concept of Transformational Leadership has described that transformational leadership is the process where the leaders and the subordinates have been working together to reach the higher extent of moral and motivation. In order to clarify the position of transformational leadership (transform the value), he differentiated it with the transactional leadership (sell and buy the value). On the other word, transformational leadership has tried to build up the awareness of the subordinates by pronouncing the big dreams and high morality such as prosperity, togetherness and humanity.

A leader is called transformation when it is measured according to the extent of trust, obedience, admiration, loyalty and respecfulness of the followers. The followers of the transformational leader are always being motivated to do their best to pursue the goals of the organization.

The Transformational Leadership is related to the charismatic leadership. Charisma is an important part of the transfornational leadership, but charisma itself is not in the position to execute the transformation process. The big difference of transformational leadership is that it has tried to give the authority according to the the capacity of each one responsibility and to develop his subordinates, but charismatic leadership has tried to make their subordinates powerless, so that they will always be depending on the leader.

Theory of transformational leadership is such a famous and modern approach which has been discussed for the last two decades. The origin idea of transformational leadership model is developed by James Mc-Gregor Burns who has applied it in the context of politic and furthermore it has been applied in the organizational context by Bernard Bass..

Bass, Bernard M, and Avolio (2006:p.128) described that in order to know more about the concept of transformational, there is a transactional leadership which is a leader who has kept or continued the status quo. This kind of leadership is defined as a leader who has been involving an exchange process where the subordinates will receive a direct and real feedback after doing the leader instructions.

Meanwhile, the transformational leadership is the leadership being disputed due to keeping the status quo. This transformational leadership is defined as the real leadership

Ratno. Relationship between Transformational Leadership and Motivation with Employee Job Performance at KPU Bogor City and Bogor Regency 
since it has been directing the organization to pursue the goals which have never been achieved before. The leaders have to be able to direct the organization to pursue a new direction actually.

Burns, James MacGregor (2000:p.167), a leader is not only the leader who can make the process of changing happened only by the intention of the subordinates or the Transactional Leadership, and for the new subordinates who have just been learning, furthermore, the leaders should have been able to develop or to direct them to the right direction, higher morality or motivation which is Transformational Leadership. Nevertheless, transformational leadership ultimately becomes moral in that it raises the level of human conduct and ethical aspiration of both leader and the led, and thus it has a transforming effect on both.

Transformational Leadership is defined as the leadership which involves the the organization change (it is being disputed because it is designed to keep the status quo) This leadership is also defined as the leadership which requires an effort to motivate the subordinates be ready to work together to pursue the superior goals of the organization instead of indivual needs.

The intention of people upon the leadership in the process of management of change has appeared when people are fully aware of the mechanism approach which has been used so far to describe the phenomena of changing, sometimes it is contradicted with people perception about the change itself since it has made the work place more humanbeing.

Defining the process of management of change, it is usually applying humanbeing transformational approach where work environment is participative, a chance of selfdevelopment, and open considered as the background of the process. However, in practice, the process of management of change has been organized based on the mechanism of transactional approach technically, where humanbeing has tended to be considered as the economical entity which is ready to be manipulated using the reward system and negative feedback in connection with the effort of the organization to get the biggest economical benefits.

Transformational leader can change the status quo of the organization by applying the behaviour practice which is in compliance with each step of the transformation process. If the previous way is not in compliance with it anymore, the leader should have to design a new vision for the future focusing to the strategical and motivational vision, The vision is describing absolutely the organization goals and having the function of inspiration resources and commitment..

Burns, James MacGregor (2000:p127) Transformational Leadership is a leadership involving all the element of the members of organization/people in their leadership. Therefore, leadership is not only consisting of the people who are leading their subordinates but also involving the followers in the process of their leadership. It is based on the assumption that people condition are powerful, and the extent of individual capacity between the follower and the leader is very closed (it means they are equal). The people do not need any longer the leaders who can do anything and give the instruction only, but they need a leader who can gather the aspiration of both parties to establish a systematic institution.

Furthermore, the transformational leadership is relying more on the future vision designed based on mutual consensus between the leaders and the followers. That is why the leader has no longer become the only one who is delivering the vision to the followers, the leader should have to be an interpreter of the vision together with the followers to transform it into the real mutual collective job.

Elizabeth O'Leary (2001: p.107),Transformational Leadership is the leadership style applied by the managers if they want to enlarge the team and have the job performance which is beyond the status quo or to reach a chain of new organization goals. Transformational leadership principally is motivating the subordinates to do their

Ratno. Relationship between Transformational Leadership and Motivation with Employee Job Performance at KPU Bogor City and Bogor Regency 
best, on the other word, the leaders can improve their subordinates' trustworthy or selfawareness which will affect the increasing of their job performance.

Avolio BJ, Zhu W, Koh W, Bhatia P (2004: p.68) described that the characteristics of transformational leadership as follows;

1. Idealized influence (or charismatic influence); Idealized influence describes that a transformational leader should be charismatic which can do a 'magic' to make the subordinates follow his leading. In fact, charismatic is demonstrated by the behavior of the people who understand the organization's vision and mission, have a strong commitment and consistent against any decision made and appreciate the subordinates accordingly. On the other words, the transformational leaders are adorable role model, appreciated and followed by their subordinates.

2. Inspirational motivation:

Inspirational motivation means that the character of the leaders who are able to implement high job standard and can push their subordinates to achieve the related job standard. This kind of character is able to evolve a high optimistic and antusiastic subordinates. On the other word, transformational leaders is always inspiring and motivating their subordinates.

3. Intellectual stimulation

Intelectual stimulation is the character of transformational leaders who can drive their subordinates enable solving the problems arisen carefully and rationaly. In spite of that, their character has been driving the subordinates discovering a new effective way to solve the problems accordingly. On the other words, transformational leader should have been able to stimulate the subordinates to be creative and innovative.

4. Individualized consideration

Individualized consideration means the character of a leader who is fully aware of the individual differences of the subordinates. In this case, transformational leader is eager and able to listen, to educate and to train the subordinates..Besides that, the transformational leaders are able to see the potential competence of their subordinates and their needs to develop, therefore, the leaders should have facilitated it. On the other word, the transformational leaders are able to understand and appreciate their subordinates based on their needs to improve their job performances and their development.

\section{The Essence of Job Motivation}

Danang Sunyoto (2012:p.191) motivation comes from the word movere means a push or moving energy, this motivation is important because it is expected to make the employees work hard and eager to achieve high productivity.

Sadili Samsudin (2006: p.281) Motivation is something that can push the spirit of the people to work which is influenced by some factors such as supervision, physical facility, wisdom, rules, reward either financial or non financial, job and challenges.

Hasibuan (2002:p.40) described that job motivation is a driven effort to create the spirit of employees to work together, effective and integrate with all efforts reaching the satisfaction. Nevertheless, motivation is the way how to direct and to improve the subordinates' potential to work cooperatively and productively to reach the goals. Motivation is very important because it is supporting, delivering the spirit of people to work hard to reach the optimum result.

Robbins (2009 : p.95) described job motivation is the process of the intensity, direction and efforts of the individual to pursue the achievement. Motivation is the reason for someone to do something. Someone who does not do anything is the one who does not have any motivation. Such the reason can come from the internal of external of the people. As a matter of fact motivation is coming from the inside of the people, but the external factors are only the trigger of being motivated.

Ratno. Relationship between Transformational Leadership and Motivation with Employee Job Performance at KPU Bogor City and Bogor Regency 
M. Fuad, et al (2008 : 97) demonstated that job motivation is the process of spirit given to the employees to work well to pursue the organization goals effectively and efficiently. However, giving a motivation, the manager has to influence the behavior of his subordinates to do their job according to the organization goals. The important factors influencing the motivation are as the following:

1. Personal's needs

2. Objective and Individual or team perception.

3. The way how to make needs, objective and perception come true.

In the organization, the productivity in the business, job motivation are very important to be taken care seriously by the managers. Refers to the four considerable main factors as follows;

1. Phylosophy of human being is refered to quit pro quo which means the reward / feecback.

2. Dynamically people needs which is complex and is not only depending on the material, but also psychological factors.

3. There is not any limit to satisfy people need.

4. Varied individual characteristic in the organization or company, has caused none of effective technics of motivation can be implemented to all the people in the organization.

A distinguished Job motivation theory is the theory of hierarchy of needs from Abraham Maslow described on his book Motivation and Personality which is described by Maslow in Robbins' book hypothezing that everyone has the hierarchy of eight needs, as follows:

1. Physiology: covering hunger, thirsty, shelter, sex, and other physical needs.

2. Safety / security : covering safe from physical or emotional attack.

3. Social: covering love, belongings, acceptance and acquantainance.

4. Appreciation; covering factors of internal appreciation or self-respect, autonomous, achievement; and external factors such as status, appreciation and attention.

5. Cognitive; knowledge needs

6. Estetics needs; beauty, balance, shape, etc.

7. Self-actualization. Self-development to be the one he wants to be.

8. Transcedents need. Helping other people to achieve self-actualization.

Referring to some job motivation theories above, the writer has concluded that job motivation is a moving driven coming up due to either internal or external factors which push someone to do or not to do something to reach a certain achievement. The motivation indicators are as follows: 1) internal motivation; a) taking responsibility, b) efforts to achieve the target, c) power passion, d) affiliates. 2) external factors: a) performance achievement, b) physical working condition, c) trying to fulfill his living requirement and job needed, d) appreciation, e) receive the intensive of job fulfillment, f) appreciation from superior or peers.

\section{Research Hypothesis}

Based on the description above, the hypotheses offered are as follows;

1. There is a positive relationship between transformational leadership and the employee's job performance.

2. There is a positive relationship between job motivation and employee's job performance.

3. There is a positive relationship between transformational leadership and job motivation simultaneously with the employees' job performance.

Ratno. Relationship between Transformational Leadership and Motivation with Employee Job Performance at KPU Bogor City and Bogor Regency 


\section{RESEARCH METHOD}

Research method has applied causal research which is a research being used to prove the connection of one variable with other variables. Data has applied quantitative data which is result of the survey obtained by distribution the questionnaires to the customers as the respondents. Total of the samples is 80 persons representing the population.

Hypothesis test is using the correlation method as follows;

1. Correlation between transformational leadership and employees job performance. rXt-y

2. Correlation between job motivation and employees' job performance. $\mathrm{rx}_{1}-\mathrm{y}$

3. Correlation between the transformational leadership and job motivation simultaneously with the employees' job performance. $\mathrm{rx}_{1}-\mathrm{x}_{2} . \mathrm{y}$

\section{RESULT OF DESCRIPTION}

1. A closed correlation between the transformational leadership and employees' job performance.

Result of the research has indicated a closed correlation between transformational leadership and employees' job performance has obtained the correlation coefficient of 0.652 . It has identified that the correlation between the transformational leadership and the employees' job performance is very strong.

The percentage or determinant coefficient between the transformational leadership $\left(\mathrm{X}_{1}\right)$ and the employees' job performance $(\mathrm{Y})$ is $42.5 \%$, however, the remaining of $57.5 \%(100 \%-42.5 \%)$ is affected by other variables which are not included in this research.

And functional or regression correlation between the transformational leadership and employees' job performance at KPU Bogor city and regencies has obtained the equation of functional or regression correlation, $\hat{Y}=48,071+0,528 X_{1}$.

The research done by the writer is along with the research done by Pebriani with the title of The Relationship of Transformational Leadership with the Employees' job performance at Forestry Department (PT Perkebunan Nusantara V Pekanbaru). And the result of correlation coefficient value ( $r$ count) between the transformational leadership and the employees' job performance is 0.714 indicating a significant correlation between transformational leadership and employees' job performance at PT Perkebunan Nusantara V Pekanbaru was happened.

Besides that, it is in line with the research of Rosalin, N.C.M., the title is Relationship of the transformational leadership and employees' job performance against the improvement of employees job performance at PT Pertiwi Agung, Bekasi. And the result of the research has indicated that the transformational leadership style has had a medium and significant correlation with the employees' job performance which is the correlation coefficient value of 0.478 and sig. value of 0.008 .

This research has been supported too by the research of Joko Tri Utomo with the title of The Relationship between the Transformational Leadership and the Communication with the Subordinates' job performance at Vocational High School (SMK) Pelita Nusantara I, Semarang resulting that the correlation coefficient between the transformational leadership and the subordinates' job performanvce is 0.301 .

Ratno. Relationship between Transformational Leadership and Motivation with Employee Job Performance at KPU Bogor City and Bogor Regency 
2. Closed Correlation between job motivation (X2) and employees' job performance (Y)

The result of the research about the closed correlation between job motivation and employees' job performance has obtained the correlation coefficient of 0.892 . It has explained that the closed correlation between job motivation and employees' job performance is very strong.

The percentage of determinant coefficient between job motivation (X2) and employees' job performance is $79.5 \%$, but the remaining of $20.5 \%(100 \%-79.5 \%)$ is affected by other variables which are not included on this research.

Then, the functional or regression correlation between job motivation and employees' job performance at KPU Bogor city and regionals has gained the equation of the functional or regression equation of $\hat{Y}=16,051+0,848 \mathrm{X}_{2}$.

The result of this research is in line with the research done by Randi Putra with the title of The Corelation between the Leader Style and Job Motivation against the employees' job performance at Institution of Technology dan Information Study at Mataram Building Yogyakarta. The result has indicated a positive and significant correlation between Job motivation and employees' job performance at LPTI Mataram Yogyakarta which is indicating the value of $r$ count is bigger than $r$ table $(0.640>0.279)$ and sig.value is less than $0.05(0.000<0.05)$

However, it is also in line with the research done by Pebriani about the Correlation between the transformational leadership and the motivation with the employees' job performance at PT Perkebunan Nusantara $\vee$ Pekanbaru). Its result has shown the significant relationship between motivation and employees' job performance at PT Perkebunan Nusantara V Pekanbaru.

This research is also supported by the research done by Rosalin, N.C.M.(2007) about The Relationship between the Transformational Leadership and Motivation with the Employees' job performance at PT Pertiwi Agung, Bekasi. Its result has indicated that the motivation has a significant and medium connection with the variable of employees' job performance which is demonstrated by the value of correlation coefficient of 0.499 and its sig. of 0.005 .

3. Closed correlation between the transformational leadership (X1) and job motivation (X2) simultaneously with the employees' job performance $(\mathrm{Y})$.

This research about the closed positive correlation between transformational leadership (X1) and Job motivation (X2) simultaneously with the employees'job performance $(Y)$ has gained the correlation coefficient of 0.894 . It has indicated that the closed correlation between transformational leadership and job motivation upon the employees' job performance is very strong.

The percentage of determinant coefficient value between transformational leadership (X1) and Job motivation (X2) simultaneously with the employees' job performance is $80.00 \%$, but the remaining of $20.00 \%(100-80 \%)$ has been affected by other variables which are not included in this research.

Furthermore, multiple regression or functional correlation between the transformational leadership and job motivation simultaneously with the employees' job performance at KPU Bogor city and regencies has gained the equation of multiple regression or functional of $\hat{Y}=13,706+0,076 X_{1}+0,788 X_{2}$. This multiple regression equation has explained that the value of constanta (a) is 13.706 indicating that if the value of the transformation leadership(X1) and motivation(X2) is fix or 0 , the employees job performance will be 13.706. Then, the value of $b 1$ in the equation of multiple functional $Y=a+b_{1} X_{1}+b_{2} X_{2}$, so $b 1=0.076$, it explains that every increasing of 1 unit of transformational leadership (X1) it will affect the increasing of employees job performance of 0.076 unit if job motivation variable $(X 2)$ is fix. The value of b2 in the equation of multiple functional $Y=a+b_{1} X_{1}+b_{2} X_{2}, b 2=0.788$, it means that 
every increasing of I unit of job motivation (X2) will affect the increasing of the employees' job performance of 0.788 unit if the transformational leadership (X1) is fix.

This research is in line with the research of Pebriani with the title of The Relationship between the Transformational Leadership and Motivation with the Employees' job performanve at PT Perkebunan Nusantara V Pekanbaru. It has applied data analysis technic of multiple correlation. Result of the research a. The value of correlation coefficient ( $r$ count) between the transformational leadership and employees' job performance is 0.714 indicating that there is a significant correlation between the transformational leadership and the employees' job performance at PT Perkebunan Nusantara V Pekanbaru happened. b. the value of correlation coefficient ( $r$ count) between motivation and employees' job performance is 0.550 indicating a significant correlation between motivation and employees' job performance at PT Perkebunan Nusantara V Pekanbaru is happened. c. The value of correlation coefficient ( $r$ count) between the transformational leadership and motivation with the employees job performance is 0.778 which means there is a significant correlation between the transformational leadership and motivation with the employees' job performance at PT Perkebunan Nusantara V Pekanbaru happened. Then the value of determinant coefficient $(R)$ is 0.605 . It means that the percentage of the correlation between the transformational leadership and motivation with the employees' job performance at PT Perkebunan Nusantara V Pekanbary is $60.5 \%$.

This research is getting along with the research of Rosalin, N. C. M. (2007) about The Relationship of the Transformational Leadership and Motivation against the Improvement of Employees' job performance at PT Pertiwi Agung, Bekasi. The research has indicated that most gender of the respondents are $60 \%$ males of 25 years old, last education mostly is high school and 5 years of working experience. Transformational Leadership Style has had a medium and significant correlation between the variable transformational leadership and the employees' job performance indicated the correlation coefficient value of 0.478 and its sig,of 0.008 , however, the motivation has had a medium and significant correlation with the variable of employees'job performance which is indicated by the correlation coefficient value of 0.499 and its sig. of 0.005 .

\section{CONCLUSION AND SUGGESTION}

\section{Conclusion}

1. Transformational Leadership has correlated positively with the employees' job performance, and the functional correlation equation is $\hat{Y}=48,071+0,528 X_{1}$; the value of correlation coefficient of 0.652 is within the category of strong correlation refers to the contribution of transformational leadership upon the employees' job performance which is $42.5 \%$. The dimension of the variable of transformational leadership which is having the strongest correlation is X13 'intelectual stimulation" and it is having the strongest correlation with the dimension of 'punctual time' (Y3) in the variable of employees' job performance and the correlation coefficient is 0.607 which categorized strong correlation. However, the weakest correlation of this research is the dimension $\mathrm{X}_{11}$ "job quality" in the variable of transformational leadership, and it is having the weakest correlation with the dimension (Y6)'contribution for the organization' in the variable of employees' job performance indicated the correlation coefficient of 0.134 which is categorized the weakest correlation.

2. Job Motivation has positively correlated with the employees' job performance and the functional correlation function is $\hat{Y}=16,051+0,848 \mathrm{X}_{2}$; the value of correlation coefficient of 0.892 is categorized having the strongest correlation with the contribution of job motivation against the employees' job performance which is 79.5

Ratno. Relationship between Transformational Leadership and Motivation with Employee Job Performance at KPU Bogor City and Bogor Regency 
$\%$ The strongest correlation of the variable job motivation is dimension (X22), 'efforts to reach the goal' which is having the strongest correlation with the dimension of 'job quality' (Y1) in the variable of employees'job performance with the correlation coefficient of 0.869 which is categorized the strongest correlation. However, weak correlation in this research is dimension (X22) the effort to reach the goals in the variable of job motivation with the dimension (Y6)'contribution to the organization' in the variable of employees' job performance having the correlation coefficient of 0.252 which is categorized weak correlation.

3. Transformational leadership (X1) and Job motivation (X2) simultaneously have positively correlated with the employees' job performance $(Y)$ refers to the functional correlation equation $\hat{Y}=13,706+0,076 X_{1}+0,788 X_{2}$ having the correlation coefficient value of 0.894 , this correlation has indicated a very strong correlation between the variable of transformational leadership and the variable of job motivation simultaneously with the variable of employees' job performance and it has indicated the effect of transformational leadership (X1) and job motivation (X2) simultaneously has contributed the employees job performance $(\mathrm{Y})$ demonstrating the determinant coefficient of $80.00 \%$, however, the remaining of $20.00 \%(100 \%$ $80 \%$ ) has been affected by the other variables which are not included in this research.

\section{Suggestions}

1. The effort to improve the employees' job performance thru the transformational leadership is as the following.

This research has indicated that the dimension $X_{11}$ 'job quality' on the variable of transformational leadership has had the weakest correlation with the dimension (Y6)'contribution to the organization' on the variable of employees' job performance which is having the correlation coefficient of 0.134 . The writer has suggested the leaders should have been able directing their subordinates to support the organization to improve their quality at work as expected.

2. The important issues required to improve the employees' job performance thru job motivations as follows:

Referring to the result of this research about weak correlation which is the variable of job motivation, dimension (X22) the effort to pursue the goal and dimension (Y6) contribution to the organization on the variable of employees' job performance having the correlation coefficient of 0.251 categorized weak correlation, therefore, the writer has suggested the leaders should have motivated their subordinates thru the program of career ladder for the employees who have reached the achievement and the leaders should have directed their subordinates to fully contribute the organization.

3. Based on the questionnaires distribution, variable of employees' job performance has indicated the lowest grade on the item number 17 which is the employee has not finished the task on time, therefore, the management of the organization should have provided the training to improve the skills of the employees how to finish the task on time and meet the target.

4. Based on the questionnaires distribution, the variable of transformational leadership has indicated the lowest value on the item 23 which is the leaders have been working inefficiently and ineffectively, the writer has suggested the leaders should have had the spirit of hardworking and given the example of working efficient and effective to their subordinates.

5. Based on the questionnaires distribution, the variable of job motivation has indicated the lowest value of item 26 which is the organization has not yet applied a reward or punishment upon the employees who are violating the regulation, however, the

Ratno. Relationship between Transformational Leadership and Motivation with Employee Job Performance at KPU Bogor City and Bogor Regency 
organization should have applied the system of punishment and reward to the employees who have given the spirit at work.

6. Further research should have been using different variables and indicators for the purpose of future science accordingly.

\section{REFERENCES}

Achmad, Ruky. The System of Job Performance Management. Jakarta : Gramedia Pustaka Utama, 2006.

Avolio, B. J., Zhu, W., Koh, W., Bhatia, P. Transformational Leadership and Organizational Commitment: Mediating Roles of Psychological Empowerment and Moderating Role of Structural Distance. Journal of Organizational Behavior, Vol. 25, Issue 8: 951 - 968. 2004.

Bertocci, David I. Leadership in Organizations There Is a Difference between Leaders and Managers. New York: University Press of America, Inc., 2009.

Bass, B. M., Avolio. Transformational Leadership and Organizational Culture. Public Administration Quarterly. 2006.

Burns, James MacGregor. Transactional and Transformasional leadership, in Hicman, Gill Robinson, Editor Leading Organizations: Perspectives for a New era. London: Sage Publications. 2000.

Cascio. Managing Human Resources, Prodaktivity, Quality of Work Life. Mc Grow Hill.2011

Colquitt, Jason A.; Jeffery A. LePine; and Michael J. Wesson. Organizational Behavior Improving Performance and Commitment in the Workplace. New York: The McGraw-Hill Companies, Inc., 2009.

Dharma, Surya. Job Performance Management. Pustaka Pelajar: Yogyakarta. 2010.

Elizabeth O'Leary, 2001, Skills of Leadership You Need in 10 Minutes, Deddy, Yogyakarta

Fuad, M., Christin H., Nurlela, Sugiarto, Paulus, Introduction to Business. Jakarta: Gramedia Pustaka Utama, 2008.

Gomes, Faustino Cardoso. Human Resources Management, Andi, Yogyakarta. 2009.

Handoko, T. Hani, Management, Yogyakarta: BPFE, 2003.

Harari, Oren. The Leadership Secret of Colin Power. Jakarta : Gramedia Pustaka Utama, 2008.

Hasibuan, Malayu S. P. Human Resources Management, Jakarta : Bumi Aksara, 2002.

Malayu S. P. Human Resources Management, Edisi Revisi. Jakarta : Bumi Aksara, 2010.

Ilgen and Schneider, S. L. In Search of Realistic Optimism Meaning, Knowledge, and Warm Fuzziness. American Psychologist. 2006.

Ratno. Relationship between Transformational Leadership and Motivation with Employee Job Performance at KPU Bogor City and Bogor Regency 
The Management Journal of BINANIAGA Vol. 03, No. 02, December 2018

PISSN: $2527-4317$

EISSN: $2580-149 x$

Kreitner, Robert \& Kinicki, Angelo. Organizational Behaviour, Jakarta: Salemba Empat, 2005.

Mangkunegara, A. A. Anwar Prabu. Human Resource Management. Bandung: PT. Remaja Rosdakarya. 2009.

McShane, Steven L., and Mary Ann Von Glinow. Organizational Behavior. Third Edition, International Edition. New York: McGraw-Hill Companies, Inc,2005.

Michael, Amstrong, 2004. Procedure of The Research of Performance Management Translator Tony Setiawan. Tugu. Yogyakarta.

Moenir. Public Service Management in Indonesia, Jakarta: Bumi Aksara. 2009

Mohrman, Susan M. Resnick-West, Edward E. Lawler. 2009. Designing Performance Appraisal System, Michigan: Jossey Bass Inc.

Noe, Raymond A. Et al. Fundamentals of Human Resource Management $4^{\text {th }}$ edition. New York: McGraw-Hill. 2011.

Steven Lattimore McShane dan Mary Ann Von Glinow, Organizational Behavior Emerging Knowledge and Practice for the Real World, Fifth Edition. New York: The McGraw-Hill Companies, Inc., 2005.

Pierce and Gardner. Organizational Behaviour, New York: Mc Graw HilL.2010.

Rivai, Veithzal dan Mulyadi, Deddy. Leadership and Organizational Behaviour. Jakarta: Rajawali Pers, 2010.

Robbins, Stephen P., Organization Behaviour. Edisi 12, Buku 1 Jakarta: Salemba Empat, 2009.

Sadili, Samsudin. Human Resources Management. Bandung: CV. Pustaka Setia, 2006.

Sedarmayanti. Human Resources and Productivity at Work, Bandung, Mandar Maju. 2009.

Sitorus, Monang. The Effect of Communication and Leadership upon the Effective Advertisiment Tax Revenue (Case Study at Dinas Pendapatan Daerah Kota Bandung), Jurnal, (VISI 18 (1) 1 - 16, 2010.

Sutrisno, Edi, Human Resources Management, Cetakan ke-2. Jakarta: Kencana Prenada Media Group, 2010.

Sunyoto, Danang. Human Resources Management. CAPS, 2012

Sujadi, Sri Wiranti Setiyanti. Evaluation Design of the Employees Job Performance Based on The Competency of Spencer. Jurnal STIE Semarang, VOL 4, NO 1, Edisi Februari 2012 (ISSN: 2252-78261).

Yukl, Gary. Leadership in Organizations, Seventh Edition. New York: Pearson Education, Inc., 2010.

Wibowo. Job Performance Management. Jakarta : PT. Raja Grafindo Persada, 2011.

Ratno. Relationship between Transformational Leadership and Motivation with Employee Job Performance at KPU Bogor City and Bogor Regency 
Widodo. E.. 2010. The Effect of Compensation upon The Productivity Improvement of the Production Workers at PT. PRIMISSIMA in Medari Sleman Yogyakarta, Fakultas Ekonomi Universitas Ahmad Dahlan. 
The Management Journal of BINANIAGA Vol. 03, No. 02, December 2018 PISSN: $2527-4317$

EISSN: $2580-149 x$

This page intentionally be emptied.

Ratno. Relationship between Transformational Leadership and Motivation with Employee Job Performance at KPU Bogor City and Bogor Regency

Page : 54 